\title{
ASCIDIANS COMMON TO THE NORTHWESTERN NORTH PACIFIC AND THE NORTHERN NORTH ATLANTIC
}

\section{$\operatorname{AUTHOR}(\mathrm{S}):$}

Tokioka, Takasi

\section{CITATION:}

Tokioka, Takasi. ASCIDIANS COMMON TO THE NORTHWESTERN NORTH PACIFIC AND THE NORTHERN NORTH ATLANTIC. PUBLICATIONS OF THE SETO MARINE BIOLOGICAL LABORATORY 1967, 14(5): 390-390

ISSUE DATE:

1967-01-25

URL:

http://hdl.handle.net/2433/175451

RIGHT: 


\section{ASCIDIANSTCOMMON TO THE NORTHWESTERN NORTH PACIFIC AND THE NORTHERN NORTH ATLANTIC}

I have just read over R.H. Millar's Tunicata Ascidiacea (123 pp., 86 textfigs.) published by Universitets Forlaget*, Oslo on Sept. 15, 1966 as the first number of "Marine Invertebrates of Scandinavia". Eighty-five species of 10 families and 37 genera are given each with brief but sufficient description and one to several text-figures showing the most characteristic features. Also the diagnosis is given for respective families and genera. Keys to families, genera and species are presented. It is very noteworthy that the distributions of respective species in Scandinavian waters and the circumpolar waters are shown in two maps and moreover informations are given as to the holotype of respective species; of course necessary synonyms are shown. The area referred to covers, besides the coasts of Scandinavian Peninsula, the Straits of Dover, the east coast of Great Britain, the Faeroes, Iceland, the east coast of Greenland, the Polar Basin and the Baltic. Thus, this book is the first monograph of the ascidians of the northern North Atlantic, basing on existing collections.

The series "Marine Invertebrates of Scandinavia" will cover 35 different groups as seen on the back cover of the book. When all these are published, the comparison of the marine invertebrate fauna between the northern North Atlantic and the northwestern North Pacific will be made very easily and comprehensively as in the case of ascidians shown next. Twenty-five of 85 species occur in the northwestern North Pacific, too. They are:

Aplidium spitzbergense Hartmeyer, A. glabrum (Verrill), Didemnum albidum (Verrill), Ciona intestinalis (L.), Chelyosoma macleayanum Broderip, Ascidia virginea Müller, A. obliqua Alder, A. callosa Stimpson, A. prunum Müller, Dendrodoa aggregata (RAthKe), D. pulchella (Verrill), Styela coriacea (Alder \& Hancock), S. rustica (L.), S. atlantica (VAN NAME), Cnemidocarpa finmarkiensis (KIAER), C. rhizopus (Redikorzev), Pelonaia corrugata Forbes \& Goodstr, Botryllus schlosseri (Pallas), Boltenia echinata (L.), B. ovifera (L.), Halocynthia pyriformis (RATHKE), Molgula griffithsii (MACLEAY), M. retortiformis VeRRILL, Rhizomolgula globularis (PALLAs) and Eugyra glutinans (MÖLLER).

Millar's opinion to treat Hexacrobylus arcticus Hartmeyer from $891-4350 \mathrm{~m}$ off the north coast of Iceland and the Faeroe-Iceland Ridge under H. indicus OкA from 1912 fathoms off Ceylon must be noted. TAKAsI TOKIOKA — Seto Marine Biological Laboratory, Japan. (Publ. Seto Mar. Biol. Lab., XIV (5), p. 390, 1967.)

\footnotetext{
* Universitets Forlaget P.O. Box 307, Blindern Oslo 3, NORWAY. (35 N. Kr.)
} 